\title{
Deficient downstream passage through fish ladders: the case of Peixe Angical Dam, Tocantins River, Brazil
}

\author{
Fernando Mayer Pelicice and Carlos Sérgio Agostinho
}

Downstream passage through fish ladders and other facilities remains largely uninvestigated in South America. In view of this concern, we monitored ascending and descending fish movements through the fish ladder at Peixe Angical Dam, upper Tocantins River, Brazil, between September 2009 and August 2010. To investigate the extent of downstream passage, the fish fauna was sampled monthly (i) at sites upstream and downstream from the dam and (ii) inside the ladder. To distinguish between ascending and descending movements, the fish ladder remained open (permanent water flow), but a screen blocked the complete passage of fish in both directions. The results of the study indicated that the ladder restricts fish movements in both directions. Few species were found to use the ladder (31 out of 119 species recorded in the area). Moreover, monitoring revealed that downstream passage is even more limited. Only 18 species were recorded moving downstream. In addition, few fish attempted to move downstream during the year; of all fish captured in the ladder $(n=17,335)$, only $4 \%$ were descending. Species performing exclusive downstream movements were numerically rare or infrequent. Most downstream captures involved only four species. We emphasize that several species performed one-way upstream movements or showed a high density of ascending fish. Consequently, the numerical ratio between ascending and descending fish (ind. $/ \mathrm{m}^{2}$ ) showed high positive values throughout the year (644:1 on average, considering all species); migratory species showed higher ratios (1069:1). The results of the study show that the facility fails to support the downstream passage of migratory and non-migratory fishes. We conclude that the fish ladder at Peixe Angical Dam does not play a conservation role and may complicate alternative conservation efforts.

A passagem descendente de peixes em mecanismos de transposição permanece pouco investigada na América do Sul. Inspirado nessa falha, o presente estudo monitorou a escada de peixes instalada na barragem da UHE Peixe Angical, alto rio Tocantins, entre setembro de 2009 e agosto de 2010. Para investigar a extensão da passagem rio abaixo, a fauna de peixes foi amostrada mensalmente em (i) locais acima e abaixo da barragem, e (ii) dentro da escada. Para identificar corretamente movimentos ascendentes e descendentes dentro da escada, o mecanismo permaneceu aberto (fluxo permanente de água), mas uma tela impediu a passagem completa dos peixes em ambas as direções. Os resultados indicam que a escada é restritiva ao movimento dos peixes em ambos os sentidos, considerando que poucas espécies tiveram acesso ao mecanismo (de um total de 119 espécies na área, apenas 31 ocorreram na escada). O monitoramento revelou, entretanto, que a passagem descendente é consideravelmente mais limitada; apenas 18 espécies foram registradas descendo o mecanismo. Além disso, poucos peixes tentaram descer a escada ao longo do ano; de todos os peixes capturados na escada $(n=17,335)$, apenas $4 \%$ desempenhava movimentos descendentes. Espécies executando apenas movimentos descendentes tiveram baixa abundância ou foram infrequentes, e apenas quatro somaram quase toda captura. Enfatizamos que diversas espécies executaram movimentos exclusivos rio acima, ou apresentaram elevado fluxo de indivíduos subindo a escada. Consequentemente, a razão entre o número de peixes subindo e descendo o mecanismo (peixes $/ \mathrm{m}^{2}$ ) apresentou valores positivos e elevados ao longo do ano (644:1 em média, considerando todas as espécies); espécies migradoras apresentaram valores ainda maiores (1069:1). A escada é, portanto, criticamente deficiente para a descida de peixes migradores e não-migradores, facultando apenas movimentos unilaterais rio acima. Concluímos que a escada de Peixe Angical não desempenha papel conservacionista, com risco de causar impactos sobre populações de peixes e complicar esforços alternativos de conservação.

Key words: Amazon basin, Conservation, Management, Migratory fish, One-way movements.

\section{Introduction}

Fish passages have been installed in many Brazilian dams (Agostinho et al., 2008) in an attempt to restore fish movements in rivers fragmented by dams. The managers expected that migratory fish would ascend the passage to reach spawning grounds located upstream. After spawning, fish (adult and young) would migrate or drift downriver, dispersing throughout the basin. In view of this belief, more than 50 fish passages, particularly ladders, were installed in the country. In some cases, the

Universidade Federal do Tocantins, Núcleo de Estudos Ambientais (Neamb), Pós-Graduação em Ecologia de Ecótonos. Rua 3, Quadra 17, Jardim dos Ipês, 77500-000 Porto Nacional, Tocantins, Brazil. fmpelicice@gmail.com (FMP), agostinhocs@gmail.com (CSA) 
installation of these facilities was mandated by local legislation.

Until recently, the mere presence of fish passages was synonymous with successful fish conservation. As a result, these facilities were never evaluated; their functional aspects and effectiveness remained largely unknown, and the facilities acquired intrinsic value and prestige among laymen and managers. The first evaluations originated only recently and have challenged the sanctity of fishways. In fact, studies have identified important problems during upstream passage (Oldani \& Baigún, 2002; Fernandez et al., 2004; Agostinho et al., 2007a; Makrakis et al., 2007; Volpato et al., 2009). The basis of these problems is that few species are able to ascend ladders and other facilities. Downstream passage, however, generally remains uninvestigated. It is possible that this lack of study stems from the common-sense notion that upstream migration is the most critical step because upstream migrants must overcome turbulent water and swim against the flow. Downstream passage, however, would occur naturally as fish passed through the ladder.

Surprisingly, the few previous studies addressing the issue have suggested that downstream passage at large dams is more limited and complex than upstream passage. For example, young (larvae and eggs) do not drift toward downstream areas, probably because they sink in the reservoir (Agostinho et al., 2007b; Suzuki et al., 2011). In addition, the only study that rigorously evaluated the downstream passage of adult fish (Agostinho et al., 2011) revealed that downstream movements through the ladder at Lajeado Dam, Tocantins River, are virtually absent despite the large number of ascending fish recorded over the year. Except for these studies, a precise quantification of downstream migration through ladders installed in South American dams is still lacking. This situation is alarming because the absence of downstream passage means that management is ineffective. In addition, if fishways work as one-way routes, passage may complicate or threaten the conservation of fish populations on a regional level (Pelicice \& Agostinho, 2008).

In view of these concerns, the present study monitored a fish ladder installed in a large Amazonian hydropower dam, UHE Peixe Angical, upper Tocantins River. The operation of the ladder was manipulated over the course of one year to quantify downstream movements. Specifically, this research (i) evaluated the use of the ladder by the fish fauna distributed above and below the dam and (ii) quantified the intensity of upstream and downstream movements through the ladder. Our primary questions addressed the occurrence of downstream movements and the relative magnitude of downstream and upstream passage. Because such evaluations are infrequent, we hope that the present results can motivate similar evaluations of other dams and provide supportive insights for management programs in South America.

\section{Materials and Methods}

\section{Study area}

The Tocantins River is 2,750 km long and is one of the major tributaries of the lower Amazon River. Together with the Araguaia River basin (2,200 km long), it drains 760,000 $\mathrm{km}^{2}$ of central Brazil. Currently, the main channel of the Tocantins River is fragmented by seven large hydroelectric dams. Most of these dams are located in the middle and upper reaches of the basin. Peixe Angical Dam is located on the upper Tocantins River between São Salvador ( $\sim 70 \mathrm{~km}$ upstream) and Lajeado Dams ( $280 \mathrm{~km}$ downstream). The dam, with an installed capacity of $452 \mathrm{MW}$, was completed in 2006. Its wall is $39 \mathrm{~m}$ high and $6.2 \mathrm{~km}$ wide. The dam flooded $294 \mathrm{~km}^{2}$ of Cerrado savanna, forming a reservoir $120 \mathrm{~km}$ in length with a mean depth of $9.3 \mathrm{~m}$ and a water residence time of 18 days.

The dam blocked the main channel of the Tocantins River. To restore fish movements, a fish ladder was installed at the right margin of the dam. In Brazil, projects that cause severe impacts, such as large dams, are required to mitigate biodiversity loss through management actions. The fish ladder at Peixe Angical Dam is part of the management program conducted by the hydroelectric company. The fish ladder is a weir and orifice type, $576 \mathrm{~m}$ long and $5 \mathrm{~m}$ wide, with a $5 \%$ slope and a total elevation gain of $30 \mathrm{~m}$. It is located on the right bank adjacent to the powerhouse. The ladder consists of 64 weirs with submerged orifices $(0.8 \times 0.8 \mathrm{~m})$, interspersed with two surface sills $(0.5 \times 1.0$ $\mathrm{m}$ ) and five resting pools (to allow the fish to rest in still water). Weir and orifice ladders represent an improvement for fish passage in South America, which has a mega-diverse fish fauna but historically relied on imported technology (Martins et al., 2007). The presence of upper and lower orifices allows the passage of species with different behavior and swimming capabilities.

\section{Sampling}

To investigate the downstream movements of fish through the ladder, the fish fauna was sampled monthly from September 2009 through August 2010 (i) in the immediate vicinity upstream and downstream from the dam and (ii) inside the ladder. Samples were always collected according to this standardized sequence (vicinity and ladder), which required 1 or 2 days to complete.

The samples were collected at two sites in the Tocantins River, one immediately below (BELOW) and one above (ABOVE) Peixe Angical Dam. The fish were sampled with gill nets set at the water surface ( 2.4 to $18 \mathrm{~cm}$ between alternate knots, $20 \mathrm{~m}$ long and $1.7 \mathrm{~m}$ high), deployed for a period of 12 to $24 \mathrm{~h}$ and checked every $\sim 8$ hours. The nets were deployed parallel to the shore. They could not be set perpendicular to the shore due to water flow below the dam. All fish captured were transported to the laboratory, where they were identified and counted. Gill net captures were expressed as catch per unit effort (CPUE: fish $/ \mathrm{m}^{2}$ of net $/ 24 \mathrm{~h}$ ).

The fish ladder facility was experimentally manipulated to quantify upstream and downstream movements inside the ladder. The ladder remained open (permanent water flow), but the passage of fish in both directions was blocked throughout the study. These procedures allowed us to identify ascending and descending attempts and minimized the influence of fish that became disoriented in the ladder or that performed repeated updown displacements. The ladder passage was permanently blocked with a steel screen $(2 \mathrm{~m}$ high, $5 \mathrm{~m}$ wide and $2 \mathrm{~cm}$ mesh size) (Fig. 1) installed immediately above the third resting pool 
( $276 \mathrm{~m}$ from the entrance). To impede fish leaps, an additional nylon screen was installed above the main screen. To capture fish in the ladder, the water flow was decreased. We sampled the whole stretch above the screen $\left(1,435 \mathrm{~m}^{2}\right)$ and a smaller standardized area below $\left(59 \mathrm{~m}^{2}\right)$. Dipnets were used to collect all individuals in these areas. We decided to sample a smaller area below the screen because previous studies have shown that the number of ascending fish is high in this ladder (Agostinho et al., 2009). To prevent evasion by the fish, each stretch was delimited with block nets prior to the reduction of water flow.

Because the screen prevented complete passage during the study, the fish above the screen were considered potential downstream migrants (DOWN), whereas the fish below the screen were considered potential upstream migrants (UP). It cannot be assumed that all fish would successfully pass through the ladder if it was open, but it is probable that the fish inside the ladder would use the facility for dispersal. In addition, field experience and previous monitoring (Agostinho et al., 2007a; Agostinho et al., 2009) have shown that several fish species use ladders in the Tocantins River as an ascending route. Therefore, it was assumed that the fish numbers above and below the screen indicate the number of fish attempting downstream and upstream movements, respectively. Previous studies that evaluated downstream

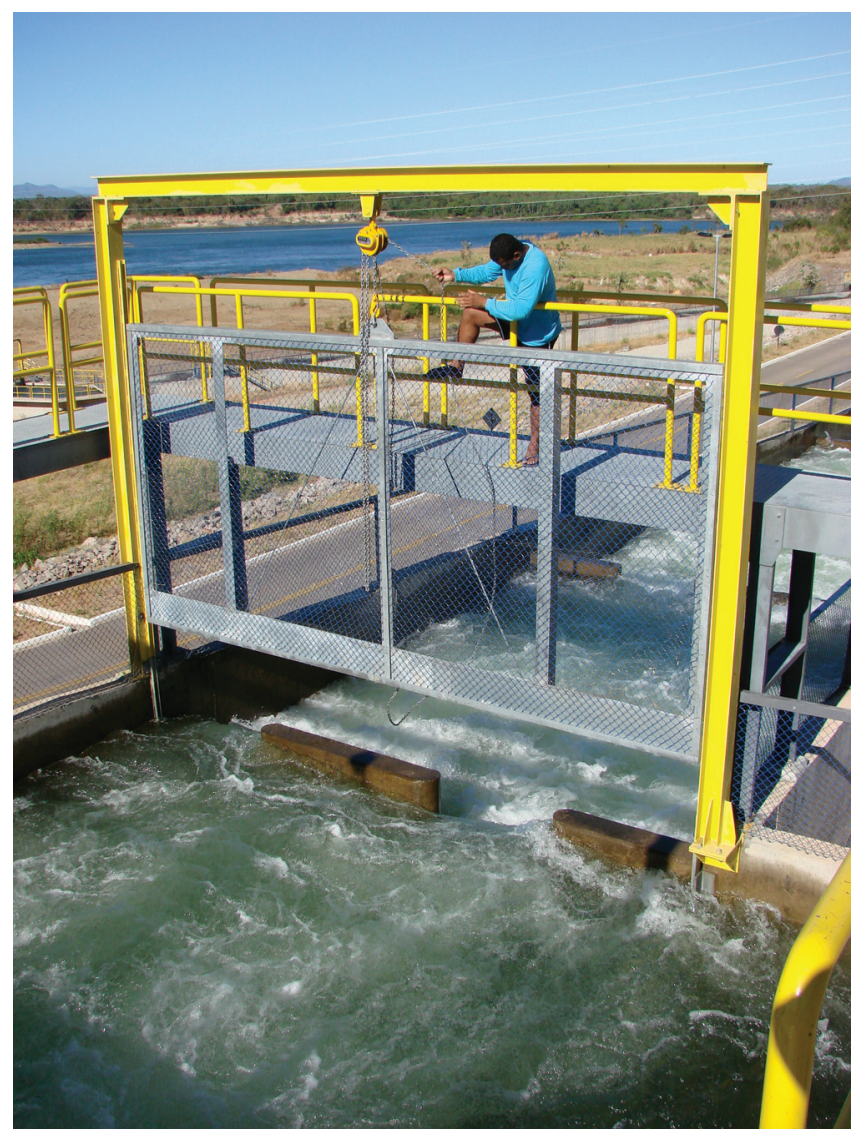

Fig. 1. Screen used to block fish passage through the ladder at Peixe Angical Dam. In this picture, the screen is shown in lifted position (before the beginning of the study). migration have blocked ladders only during sampling events (Agostinho et al., 2007b; Makrakis et al., 2007), a procedure that was unable to accurately discriminate between genuine ascending and descending movements (e.g., disoriented fish that have just ascended may be recorded as downstream migrants). The present study, following Agostinho et al. (2011), represents a considerable methodological improvement and ensures more precise measurements.

All specimens captured above the screen were transported to the laboratory for identification and counting. Below the screen, 30 fish per species/sample were kept, whereas the others were identified, counted and released. Sampling in the ladder occurred during daylight hours, and captures were expressed as fish $/ \mathrm{m}^{2}$. Voucher specimens are deposited in the Coleção de Peixes do Laboratório de Ictiologia Sistemática, Universidade Federal do Tocantins, Porto Nacional, Brazil.

\section{Data analysis}

Data analysis followed two main levels of comparison, termed contrasts: (i) a ladder $\mathrm{x}$ surroundings contrast and (ii) a downstream $\mathrm{x}$ upstream contrast.

To investigate the use of the ladder by fish assemblages located below and above the dam (ladder $\mathrm{x}$ surroundings contrast), the structure of the fish fauna was compared considering (i) ABOVE versus DOWN and (ii) BELOW versus UP. The assemblage structure was measured as species richness, abundance (CPUE) and composition. We calculated the mean difference in species richness between sites and used a Spearman correlation to investigate temporal trends in abundance and richness, evaluating the congruence between sites. The similarity of faunal composition (presence/absence data) between sites was measured with Sorensen's index. For this analysis, the data from all months were combined.

To measure the intensity of ascending and descending movement attempts through the ladder (downstream $\mathrm{x}$ upstream contrast), the captures were compared between DOWN and UP sites. The differences in mean abundance were tested with a nonparametric analysis of variance (Kruskal-Wallis), with the months representing replicates. Monthly ratios between the number of ascending and descending fish (UP/DOWN and DOWN/UP) were calculated based on the fish fauna as a whole. Ratios were also calculated separately for each species based on total captures (all months combined). A statistical significance level of $\alpha<0.05$ was used for all analyses.

Several analyses performed in this study distinguished species according to two contrasting reproductive strategies, namely, long-distance migratory and non-migratory fish. Although the entire fish fauna is affected by impoundments (Agostinho et al. 2008), the migratory species would benefit more from fish passages because the habitats used by these species for spawning, growth and feeding may be geographically segregated. The reproductive strategies of the studied species were determined according to Neuberger et al. (2009). 


\section{Results}

A total of 22,911 individuals were captured in this study, including 119 species, 7 orders, and 24 families. Characiformes and Siluriformes contributed the greatest number of species and captures, including most migratory species (13 and 10 species, respectively).

\section{Ladder x surroundings contrast}

The total species richness was lower in the ladder (UP = 26 ; DOWN $=18$; Total $=31$ ) than at the sites around the dam $(\mathrm{ABOVE}=96 ; \mathrm{BELOW}=78 ;$ Total $=115)$. Notably, few siluriform species $(\mathrm{S}=4)$ were recorded in the ladder, and this group did not occur in the DOWN samples. We found low levels of variation in species richness at all sites from month to month. Fewer species were captured moving downstream (Fig. 2), and the mean difference between the number of species moving downstream and ABOVE was $34 \mathrm{spp}$./month. The number of species moving upstream was also low (with a prevalence of migratory species), with a mean difference of $14 \mathrm{spp}$./month compared with BELOW (Fig. 2). In addition, low levels of congruence between sites (contrasts) were observed for both migratory and non-migratory species richness (Table 1).
The temporal trends in abundance showed that the ladder is seldom used by the fish assemblages above the dam. Virtually all fish captured in the ladder ( $96 \%$ of 17,335 fish) were ascending the facility (Fig. 3) and were predominantly migratory species. In the sites around the dam, higher numbers of captures occurred in BELOW, with considerable variation over time and a predominance of migratory species (Fig. 3). The site ABOVE was characterized by a low level of variation over time and a prevalence of nonmigratory fish. Low correlation values were recorded between the sites (contrasts) for both reproductive strategies (Table 1).

The assemblage composition (presence/absence data, all months combined) differed considerably between the sites, which showed low similarity values (Sorensen: ABOVE $\mathrm{x}$ $\mathrm{DOWN}=0.26$; UP $\times$ BELOW $=0.27$ ). The principal species moving downstream (85\% of total captures: Prochilodus nigricans, Leporinus affinis and Schizodon vittatus) had a low capture percentage above the dam $(2.8 \%)$. Similarly, the principal species ascending the ladder $(88 \%$ of total captures: Oxydoras niger, P. nigricans and Serrassalmus rhombeus) had a low capture percentage below the dam $(12.2 \%)$.

\section{Downstream x upstream contrast}

The mean fish density was significantly higher in UP than in DOWN (Fig. 4) for both migratory (Kruskal-Wallis: H(1,
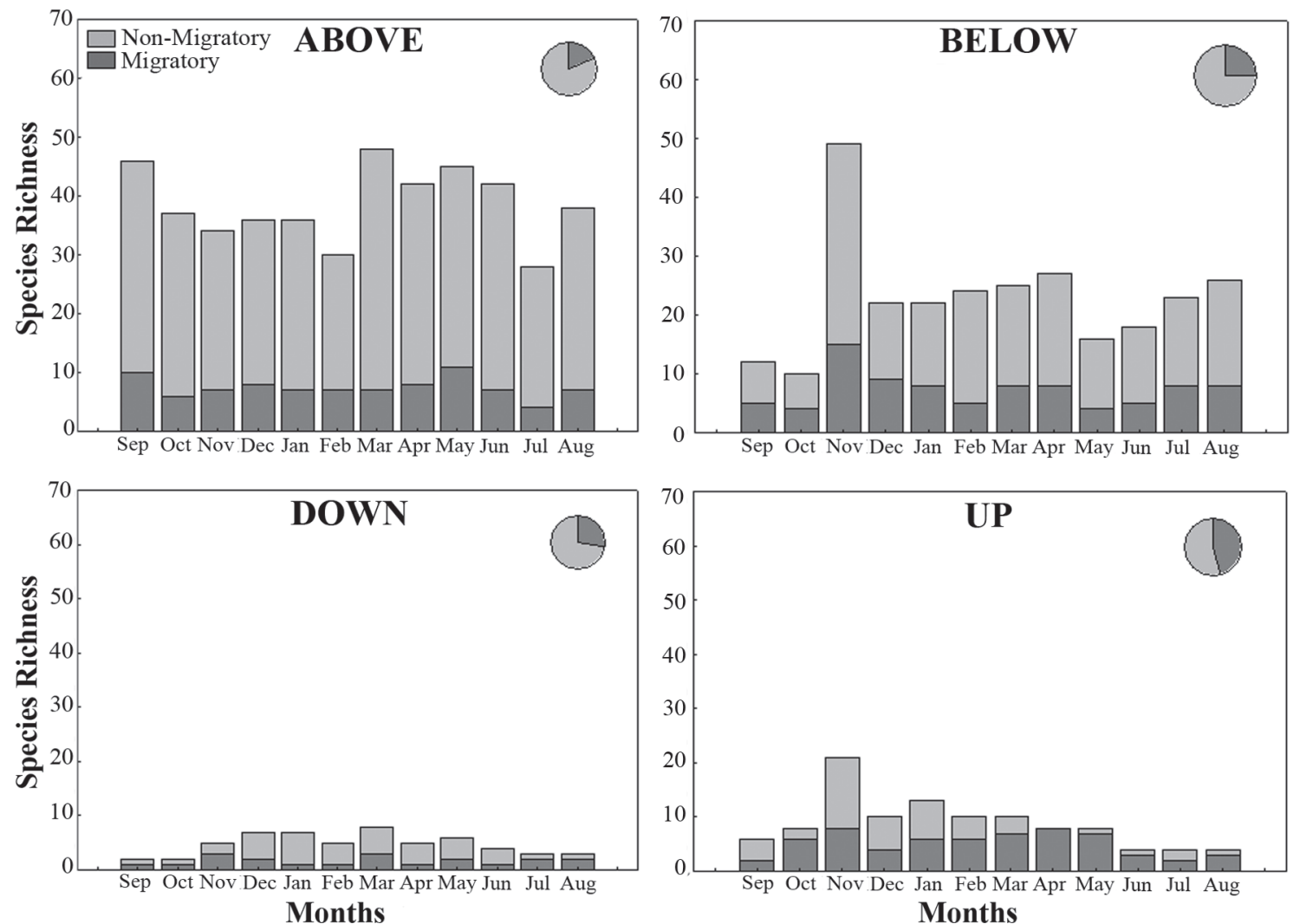

Fig. 2. Temporal trends in species richness of migratory and non-migratory fish captured around the dam (ABOVE and BELOW) and inside the ladder (DOWN and UP). Small charts indicate the contribution (\%) of migratory and non-migratory species over the entire period. 
Table 1. Congruence (Spearman correlation) in the distribution of species richness and abundance (migratory and nonmigratory fish) from month to month in terms of the contrasts ABOVE $x$ DOWN and UP $x$ BELOW.

\begin{tabular}{lcccccc}
\hline & \multicolumn{2}{c}{ ABOVE x DOWN } & & \multicolumn{2}{c}{ BELOW x UP } \\
\cline { 2 - 3 } \cline { 5 - 6 } & $\mathrm{r}$ & $\mathrm{p}$ & & $\mathrm{r}$ & $\mathrm{p}$ \\
\hline Species richness & & & & & \\
Migratory & -0.05 & 0.8798 & & 0.17 & 0.5997 \\
Non-migratory & 0.04 & 0.9114 & & 0.1 & 0.7546 \\
\hline Abundance & & & & & \\
Migratory & -0.15 & 0.6324 & & 0.31 & 0.3306 \\
Non-migratory & -0.13 & 0.6795 & & 0.3 & 0.3473 \\
\hline
\end{tabular}

$\mathrm{N}=24)=17.3 ; \mathrm{p}<0.0001)$ and non-migratory species $(\mathrm{H}(1$, $\mathrm{N}=24)=9.7 ; \mathrm{p}<0.0018$ ). As previously stated, almost all fish $(96 \%)$ captured in the ladder were moving upstream. As a consequence, the numerical ratio of ascending to descending fish (UP/DOWN) showed high positive values throughout the year (Fig. 5), especially between September and April. The UP/DOWN ratio ranged between 21:1 and 1776:1, with a mean ratio of 644:1. Higher values were observed for migratory species (Fig. 5), primarily between January and March, with a mean value of 1069:1.
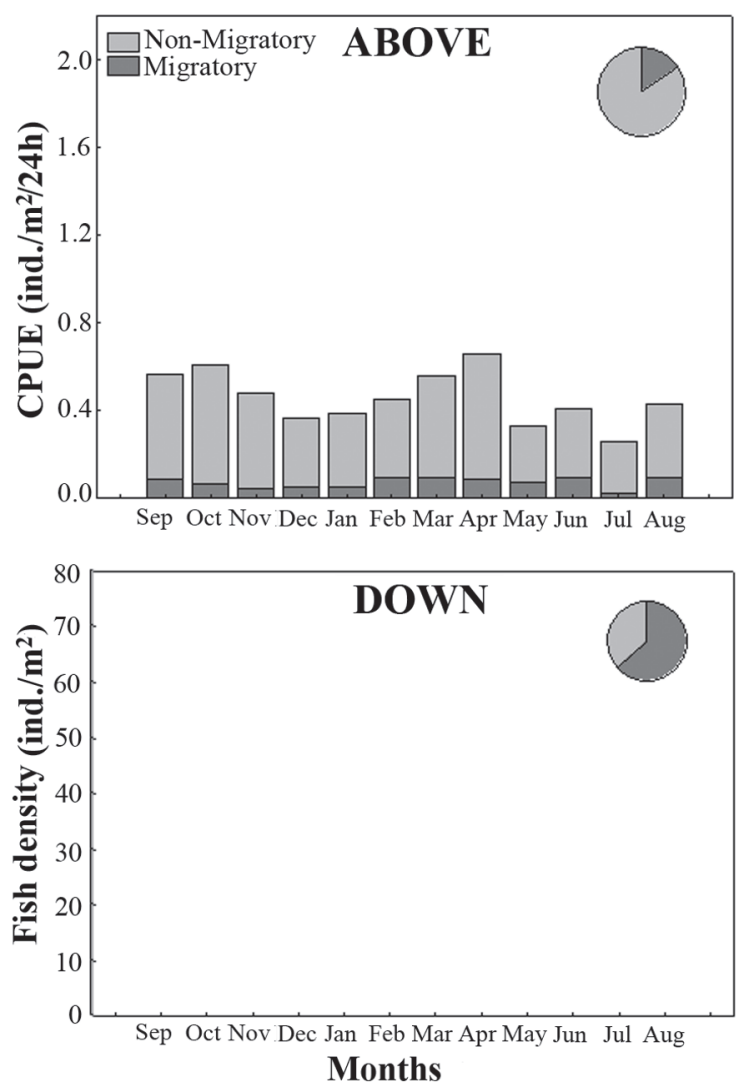

Individually, most species showed positive UP/DOWN ratios or moved exclusively upstream. These species included the non-migratory S. rhombeus and the migratory $O$. niger, Hydrolycus armatus, Leporinus trifasciatus, Argonectes robertsi, P. nigricans and Pseudoplatystoma fasciatum (Table 2). Certain species showed very high ratios in excess of 500:1. Species that moved exclusively downstream showed low captures and rarely occurred in the ladder (Table 2).

\section{Discussion}

Our results indicated that the ladder at Peixe Angical Dam is very selective. The structure of the fish fauna (abundance, richness, composition) differed markedly between the ladder and the sites around the dam. This result indicated that few species use the ladder. However, the principal finding of the study is that downstream passage through the ladder is extremely limited, considering that few downstream migrants were captured in the ladder during the study. This trend was clear from the comparison of downstream movements with upstream movements: ascending fish represented $96 \%$ of all captures in the ladder. By quantifying the movement of the descending fish into the ladder, the present study showed that effective downstream passage constitutes a genuine challenge and is more complex than upstream passage.
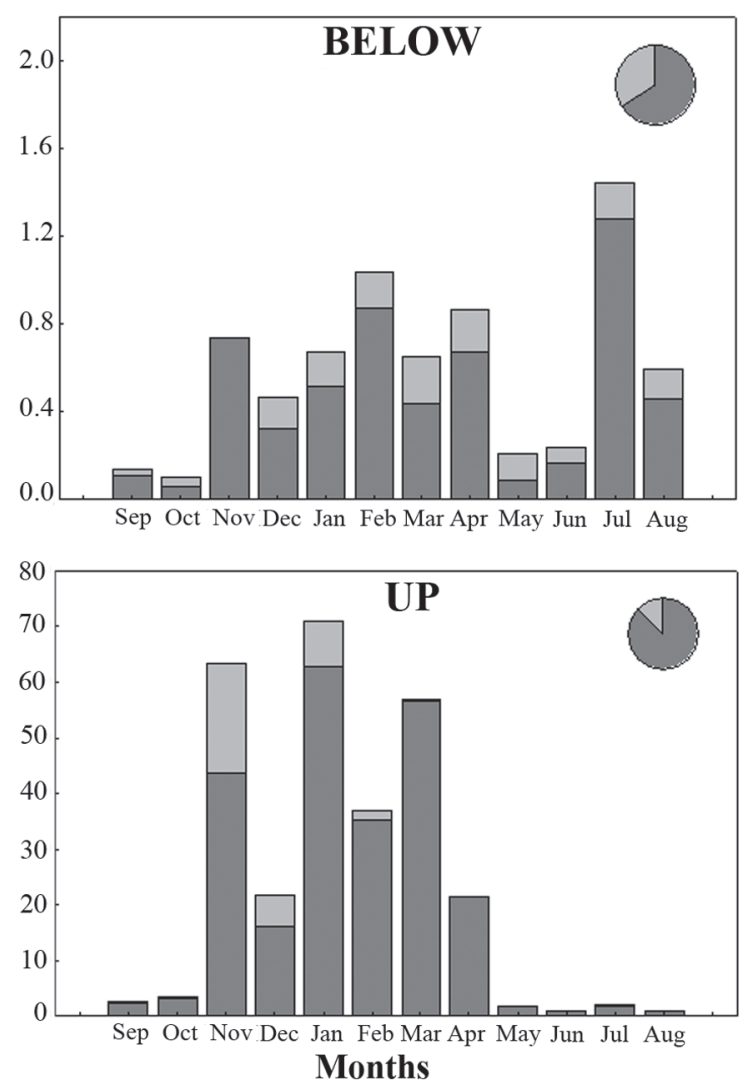

Fig. 3. Temporal trends in fish abundance recorded around the dam (ABOVE and BELOW; fish $/ \mathrm{m}^{2}$ of net $/ 24 \mathrm{~h}$ ) and inside the ladder (DOWN and UP; fish $/ \mathrm{m}^{2}$ ). Small charts indicate the numerical contribution (\%) of migratory and non-migratory species over the entire period. 

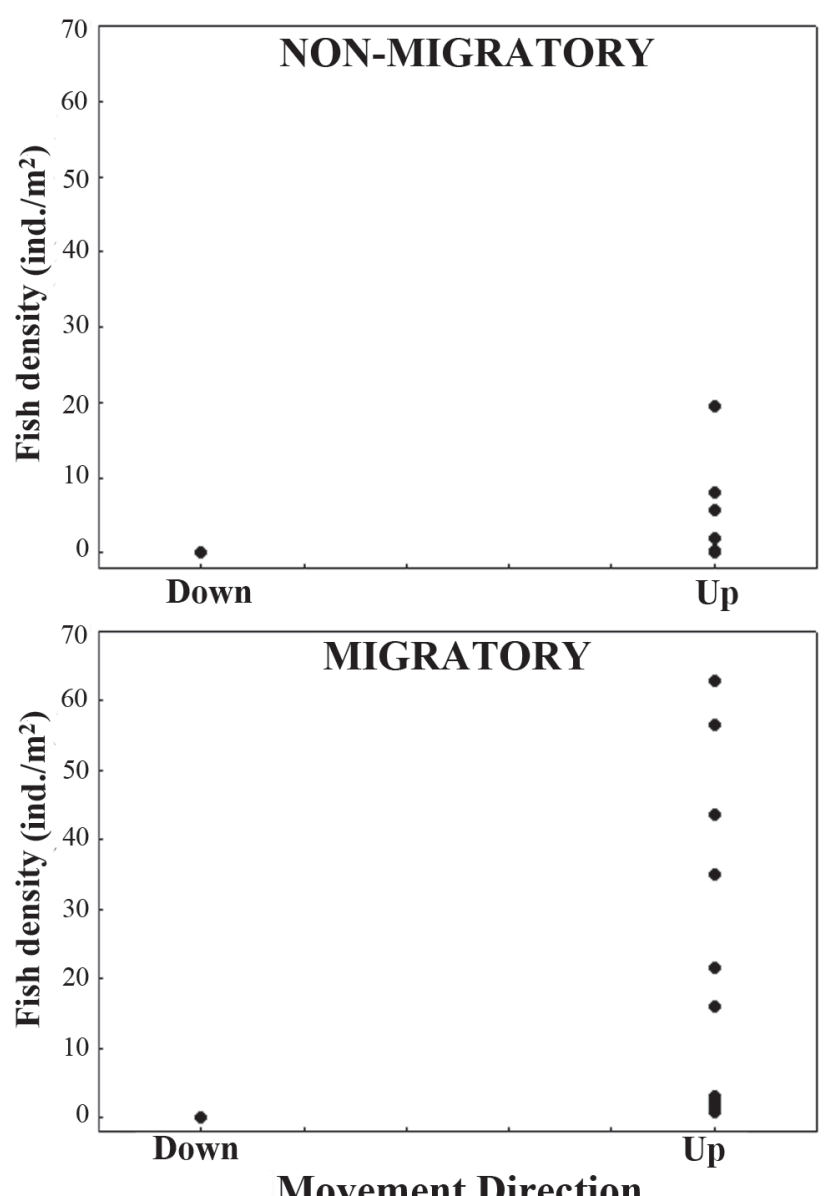

Fig. 4. Density of fish (ind. $\left./ \mathrm{m}^{2}\right)$ descending (DOWN) and ascending (UP) through the ladder between September 2009 and August 2010 (dots represent monthly samples; $\mathrm{N}=12$ ).

In fact, few fish attempted to move downstream over the year ( $4 \%$ of all fish), and most captures involved only four species (P. nigricans, L. affinis, M. setiger, and S. vittatus). We emphasize that species performing exclusive downstream movements were numerically rare or infrequent, whereas several species performed one-way upstream movements or showed large numbers of ascending fish. The facility is, therefore, critically insufficient to allow the downstream passage of migratory and non-migratory fish. Alternatively, downstream passage could occur through the drift and dispersal of larvae and eggs. However, the construction of Peixe Angical Dam altered the spatial distribution of eggs and larvae along the river corridor (Pinto et al., 2009), and eggs and larvae disappeared from sites near the dam. In addition, Freitas et al. (2009) reported a very low density of eggs and larvae in the ladder, showing that young fish rarely pass through the ladder. Note that similar patterns were observed for both adult and young fish in the ladder at Lajeado Dam, located downstream from the study site. At Lajeado Dam, fish migrating downstream were virtually absent from the
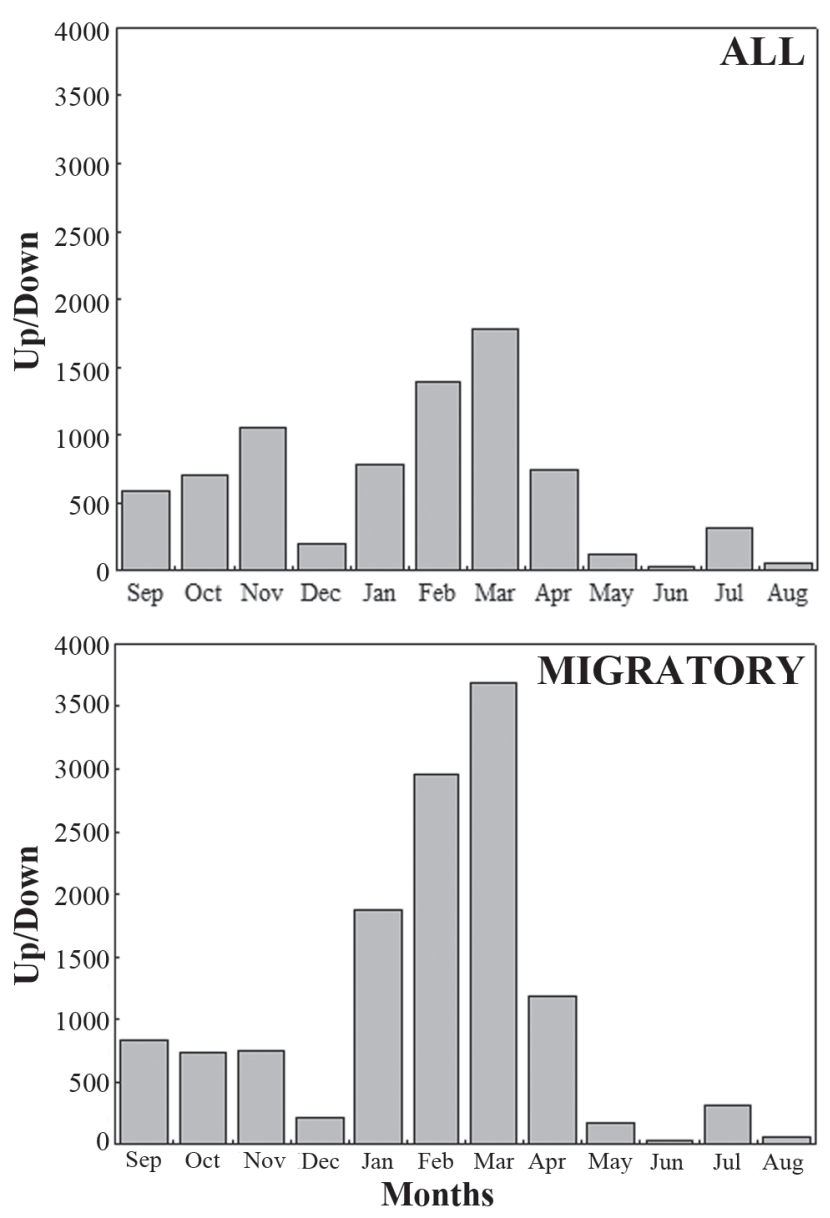

Fig. 5. Ratio between the number of fish (ind. $/ \mathrm{m}^{2}$ ) ascending and descending through the ladder (UP/DOWN), between September 2009 and August 2010.

ladder (Agostinho et al., 2011), and the abundance of eggs and larvae declined dramatically along the reservoir (Agostinho et al., 2007b). The similar trends observed at Peixe Angical and Lajeado, together with other evaluations (Agostinho et al., 2007b; Lopes et al., 2007; Pelicice \& Agostinho, 2008; Suzuki et al., 2011), indicate that large Neotropical dams may fail to allow the downstream passage of young and adults.

Note that passage was deficient in both directions considered in this study. The structure of the fish fauna in the ladder showed only a low level of correspondence with the fish fauna in the sites around the dam. A few species represented almost all captures in the facility. This result suggested that most species do not use the ladder, a trend reported in different river basins (Godinho et al., 1991; Oldani \& Baigún, 2002; Fernandez et al., 2004; Agostinho et al., 2007a; Makrakis et al., 2007; Agostinho et al., 2009). At Peixe Angical Dam, large numbers of $O$. niger, P. nigricans, S. rhombeus, L. affinis and a few other species are expected to ascend the ladder successfully. The ascending migrations 
Table 2. Mean density (DENS: fish $/ 100 \mathrm{~m}^{2}$ ), relative density (DENS\%) and occurrence (OC\%) of species ascending and descending the ladder for monthly captures between September 2009 and August 2010. The ratio between ascending and descending fish (ind./m²; UP/DOWN and DOWN/UP) is also shown. The symbol "+" indicates one-way movements.

\begin{tabular}{|c|c|c|c|c|c|c|c|c|c|}
\hline \multirow{2}{*}{ Species } & \multirow[b]{2}{*}{ Voucher } & \multicolumn{3}{|c|}{ Ascending (UP) } & \multicolumn{3}{|c|}{ Descending (DOWN) } & \multicolumn{2}{|c|}{ Ratio } \\
\hline & & DENS & DENS $\%$ & $\mathrm{OC} \%$ & DENS & DENS $\%$ & $\mathrm{OC} \%$ & UP/DOWN & DOWN/UP \\
\hline \multicolumn{10}{|l|}{ Non-migratory } \\
\hline Boulengerella cuvieri & UNT 2274 & & & & 0.07 & 0.16 & 8.3 & & + \\
\hline Caenotropus labyrinthicus & UNT 7612 & 1.7 & 0.01 & 8.3 & & & & + & \\
\hline Cichla piquiti & UNT 7579 & & & & 0.21 & 0.48 & 16.7 & & + \\
\hline Cichla sp. & UNT 3665 & & & & 0.07 & 0.16 & 8.3 & & + \\
\hline Crenicichla lugubris & UNT 4162 & & & & 0.07 & 0.16 & 8.3 & & + \\
\hline Hemiodus microlepis & UNT 1277 & & & & 0.07 & 0.16 & 8.3 & & + \\
\hline Hemiodus unimaculatus & UNT 8047 & 13.5 & 0.05 & 8.3 & 0.42 & 0.96 & 16.7 & 32.4 & \\
\hline Laemolyta fernandezi & UNT 3684 & 5.1 & 0.02 & 16.7 & & & & + & \\
\hline Leporellus vittatus & UNT 7734 & 3.4 & 0.01 & 16.7 & 0.14 & 0.32 & 8.3 & 24.3 & \\
\hline Leporinus affinis & UNT 8045 & 1296.1 & 4.58 & 75 & 7.59 & 17.41 & 58.3 & 170.7 & \\
\hline Leporinus friderici & UNT 1806 & 157.4 & 0.56 & 33.3 & & & & + & \\
\hline Leporinus geminis & UNT 7073 & 1.7 & 0.01 & 8.3 & 0.07 & 0.16 & 8.3 & 24.3 & \\
\hline Hypomasticus pachycheilus & UNT 4871 & 1.7 & 0.01 & 8.3 & 1.25 & 2.88 & 16.7 & 1.3 & \\
\hline Leporinus tigrinus & UNT 7677 & 37.2 & 0.13 & 8.3 & & & & + & \\
\hline Leporinus unitaeniatus & UNT 9009 & 1.7 & 0.01 & 8.3 & & & & + & \\
\hline Myleus setiger & UNT 7553 & 323.2 & 1.14 & 75 & 2.58 & 5.91 & 75 & 125.4 & \\
\hline Schizodon vittatus & UNT 3674 & 191.2 & 0.68 & 33.3 & 2.93 & 6.71 & 33.3 & 65.3 & \\
\hline Serrasalmus rhombeus & UNT 3002 & 1582.1 & 5.60 & 50 & 0.49 & 1.12 & 41.7 & 3244.4 & \\
\hline Triportheus trifurcatus & UNT 6910 & 8.5 & 0.03 & 16.7 & & & & + & \\
\hline \multicolumn{10}{|l|}{ Migratory } \\
\hline Argonectes robertsi & UNT 8048 & 233.5 & 0.83 & 33.3 & 0.49 & 1.12 & 16.7 & 478.8 & \\
\hline Brycon falcatus & UNT 3083 & 6.8 & 0.02 & 16.7 & & & & + & \\
\hline Brycon gouldingi & UNT 6581 & 6.8 & 0.02 & 16.7 & & & & + & \\
\hline Hydrolycus armatus & UNT 3702 & 387.5 & 1.37 & 75 & 0.21 & 0.48 & 16.7 & 1854.1 & \\
\hline Leporinus trifasciatus & UNT 9777 & 191.2 & 0.68 & 58.3 & 0.28 & 0.64 & 16.7 & 686.2 & \\
\hline Myleus torquatus & UNT 6873 & 18.6 & 0.07 & 33.3 & 0.14 & 0.32 & 16.7 & 133.6 & \\
\hline Oxydoras niger & UNT 5347 & 18583.8 & 65.73 & 66.7 & & & & + & \\
\hline Piaractus brachypomus & UNT 7761 & 66.0 & 0.23 & 25 & & & & + & \\
\hline Prochilodus nigricans & UNT 3061 & 4739.4 & 16.76 & 100 & 26.54 & 60.86 & 100 & 178.6 & \\
\hline Pseudoplatystoma cf. fasciatum & UNT 7737 & 409.5 & 1.45 & 66.7 & & & & + & \\
\hline Sorubim lima & UNT11597 & 1.7 & 0.01 & 8.3 & & & & + & \\
\hline Zungaro zungaro & UNT 8508 & 3.4 & 0.01 & 16.7 & & & & + & \\
\hline
\end{tabular}

of these species may produce excessive numbers of fish in upstream areas. In fact, the ratio between ascending and descending movements (UP/DOWN) showed high positive values throughout the year. The annual mean of these values was $644: 1$; this ratio was even greater for migratory species, exceeding 1069:1. These results indicate that the ladder essentially provides upstream passage, particularly for some migratory species. Agostinho et al. (2011) observed a very similar trend in Lajeado Dam, with a high ratio between ascending and descending fish $(\sim 1500: 1)$. In view of these results, it is probable that both ladders function as a oneway route.

The factors preventing the downstream passage of adult fish are still poorly understood, but it is possible to propose some hypotheses. For example, we recorded few migratory fish above the dam. This low level of abundance was consistent throughout the year and contrasted strongly with the trend observed below the dam, where abundance peaked during the rainy months (the period of reproductive migration, known as piracema). The scarcity of migratory species in the inner zones of impoundments has been reported by previous studies (Agostinho et al., 2007b;
Antonio et al., 2007; Agostinho et al., 2011). It is probable that this scarcity is related to the rheophilic behavior of Neotropical fish, which are typically adapted to live in riverine environments and associated habitats (Gomes \& Miranda, 2001). In areas affected by impoundments, these fish usually remain in stretches that preserve the natural flow regime, such as upper areas and tributaries. This behavior may impede downstream passage because fish do not access the ladder. This behavior may even prevent passage through alternative routes, such as the turbines and spillway, because fish do not visit the area near the dam. Therefore, the lack of potential migrants just above the dam may explain the small number of descending fish in the ladder. In addition, delayed migration may have played a complementary role. In the ladder at Lajeado Dam (Agostinho C.S., unpublished data), few fish were recorded near the exit from the ladder. Furthermore, the fish near the exit were more often outside than inside the facility. This observation indicates that the fish tend to avoid or spend much time negotiating the ladder. Therefore, few migratory fish approach the dam, and these fish appear to avoid the facility. We emphasize that several factors, including, e.g., 
structural deficiencies and hydraulics, may explain the absence of downstream passage, but the behavior of Neotropical fish must play a decisive role. Future studies must consider this issue to provide a better understanding of downstream passage.

The occurrence of one-way movements has severe consequences for fish management and conservation. Demographic impacts are expected because the unidirectional flow of individuals may permanently redistribute fish populations along the river. Among the possible short-term impacts, excessive one-way dispersal may cause rapid population increases above the dam (exceeding carrying capacity) or the complete depletion of stocks from below. In the long run, the occurrence of "ecological traps" (sensu Pelicice \& Agostinho, 2008) may have a substantial impact because fish are removed from the area between Peixe Angical and Lajeado Dams ( $\sim 270 \mathrm{~km}$ long), with large tributaries and wetlands, and delivered to a shorter river stretch (between Peixe Angical and São Salvador Dams, $\sim 65 \mathrm{~km}$ long) that contains only one large tributary, the Paranã River. Without adequate downstream passage, the fish would be confined within an area furnishing poorer ecological conditions for recruitment. In addition, the Paranã River has been targeted for hydroelectric projects. These projects will further affect migration patterns, the integrity of critical habitats and recruitment above Peixe Angical Dam. In addition, we emphasize that fish recruitment in the reservoir area has already been affected by the construction of Peixe Angical Dam. The density of eggs and larvae decreased significantly after impoundment (Pinto et al., 2009). In view of this complex context (absence of downstream passage, one-way upstream movements, the possibility of limited recruitment above the dam), we conclude that the fish ladder at Peixe Angical Dam does not play a conservation role. In addition, because the Tocantins River is fragmented by several large dams, the fish fauna is now considerably threatened at the basin scale, and conservation becomes a complex and difficult issue. Alternative management actions, such as the preservation of extensive free-flowing stretches between dams, may function more effectively (Agostinho et al., 2011).

In conclusion, problems related to downstream passage have been recognized worldwide (Jepsen et al., 1998; Larinier \& Travade, 2002; O'Connor et al., 2006; Carr \& Whoriskey, 2008; Kraabøl et al., 2009), but these problems are a new concern in South America. The basic characteristics of downstream passage (e.g., do fish pass downstream?) remain uninvestigated and largely unknown in most fishways. However, the present study showed that downstream passage is virtually absent and notably more difficult than upstream passage, a pattern that must be the rule for large dams. We hope that these results encourage future studies to consider fish passage management in its totality: a tool that must allow free traffic along the river, both upstream and downstream, as a means of maintaining fish population dynamics. We regret that fishways in Brazil continue to be installed without thorough evaluations, using misleading information and based on nebulous goals (Pompeu et al., 2012). It is clear that fish conservation in impounded areas is a complex issue, demanding broader perspectives and sound ecological information (Pelicice \& Agostinho, 2008; Kraabøl et al., 2009; Roscoe \& Hinch, 2010). As long as this broader context is neglected, the risk of installing ineffective fish passages remains. This situation can potentially complicate alternative conservation efforts.

\section{Acknowledgments}

We thank Gilmar Lino Pereira and Anderson Brito Soares for their logistical support and assistance with field and laboratory work. Enerpeixe S.A. provided financial funding.

\section{Literature Cited}

Agostinho, A. A., E. E. Marques, C. S. Agostinho, D. A. Almeida, R. J. Oliveira \& J. B. M. Rodrigues. 2007b. Fish ladder of Lajeado Dam: migration on one way routes? Neotropical Ichthyology, 5: 121-130.

Agostinho, A. A., F. M. Pelicice \& L. C. Gomes. 2008. Dams and the fish fauna of the Neotropical region: impacts and management related to diversity and fisheries. Brazilian Journal of Biology, 68: 119-1132.

Agostinho, C. S., A. A. Agostinho, F. M. Pelicice, D. A. Almeida \& E. E. Marques. 2007a. Selectivity of fish ladders: the first bottleneck in fish movement. Neotropical Ichthyology, 5: 205-213.

Agostinho, A. A., C. R. Pereira-Assis \& R. J. Oliveira. 2009. Seletividade no ingresso e ascensão de peixes na escada de Peixe Angical. Pp. 139-148. In: Agostinho, C. S., F. M. Pelicice \& E. E. Marques (Eds.). Reservatório de Peixe Angical: bases ecológicas para o manejo da ictiofauna. São Carlos, RiMa Editora.

Agostinho, C. S., F. M. Pelicice, E. E. Marques, A. B. Soares \& D. A. A. Almeida. 2011. All that goes up must come down? Absence of downstream passage through a fish ladder in a large Amazonian river. Hydrobiologia, 675: 1-12.

Antonio, R. R., A. A. Agostinho, F. M. Pelicice, D. Bailly \& J. H. P. Dias. 2007. Blockage of migration routes by dam construction: can migratory fish find alternative routes? Neotropical Ichthyology, 5: 177-184.

Carr, J. W. \& F. G. Whoriskey. 2008. Migration of silver American eels past a hydroelectric dam and through a coastal zone. Fisheries Management and Ecology, 15: 393-400.

Fernandez, D. R., A. A. Agostinho \& L. M. Bini. 2004. Selection of an experimental fish ladder located at the dam of the Itaipu Binacional, Paraná River, Brazil. Brazilian Archives of Biology and Technology, 47: 579-586.

Freitas, I. S., E. E. Marques, J. R. B. Melo, E. S. Araújo \& M. D. S. Pinto. 2009. Composição e abundância do ictioplâncton na escada de Peixe Angical e suas imediações. Pp. 159-164. In: Agostinho, C. S., F. M. Pelicice \& E. E. Marques (Eds.). Reservatório de Peixe Angical: bases ecológicas para o manejo da ictiofauna. São Carlos, RiMa Editora.

Godinho, H. P., A. L. Godinho, P. S. Formagio \& V. C. Torquato. 1991. Fish ladder efficiency in a southeastern Brazilian river. Ciência e Cultura: Journal of the Brazilian Association for the Advancement of Science, 43: 63-67.

Gomes, L. C. \& L. E. Miranda. 2001. Riverine characteristics dictate composition of fish assemblages and limit fisheries in reservoirs 
of the Upper Paraná River Basin. Regulated Rivers: Research \& Management, 17: 67-76.

Jepsen, N., K. Aarestrup, F. Økland \& G. Rasmussen. 1998. Survival of radio-tagged Atlantic salmon (Salmo salar L.) and trout (Salmo trutta L.) smolts passing a reservoir during seaward migration. Hydrobiologia, 371/372: 347-353.

Kraabøl, M., S. I. Johnsen, J. Museth \& O. T. Sandlund. 2009. Conserving iteroparous fish stocks in regulated rivers: the need for a broader perspective! Fisheries Management and Ecology, 16: 337-340.

Larinier, M. \& F. Travade. 2002. Downstream migration: problem and facilities. Bulletin Français de la Peche et de la Pisciculture, 364 (supplément): 181-207.

Lopes, C. M., F. S. Almeida, M. L. Orsi, S. G. C. Britto, R. N. Sirol \& L. M. K. Sodré. 2007. Fish passage ladders from Canoas Complex - Paranapanema River: evaluation of genetic structure maintenance of Salminus brasiliensis (Teleostei: Characiformes). Neotropical Ichthyology, 5: 131-138.

Martins, S. L., C. S. Agostinho \& K. Tamada. 2007. Biohydraulical conception of a neotropical fish passage. Pp. 27-46. In: Pompeu, P. S., H. S. Santos \& C. B. M. Alves. (Eds.). Proceeding of the International Symposium on Fish Passages in South America. Lavras, UFLA, 100p.

Makrakis, S., M. C. Makrakis, R. L. Wagner, J. H. P. Dias \& L. C. Gomes. 2007. Utilization of the fish ladder at the Engenheiro Sérgio Motta Dam, Brazil, by long distance migrating potamodromous species. Neotropical Ichthyology, 5: 197-204.

Neuberger, A. L., E. E. Marques, C. S. Agostinho \& F. M. Pelicice. 2009. Variações espaciais na atividade reprodutiva de peixes na área de influência do reservatório de Peixe Angical. Pp. 59-68. In: Agostinho, C. S., F. M. Pelicice \& E. E. Marques (Eds.). Reservatório de Peixe Angical: bases ecológicas para o manejo da ictiofauna. São Carlos, RiMa Editora.
O’Connor, J. P., D. J. O’Mahony, J. M. O’Mahony \& T. J. Glenane. 2006. Some impacts of low and medium head weirs on downstream fish movement in the Murray-Darling Basin in southeastern Australia. Ecology of Freshwater Fish, 15: 419-427.

Oldani, N. O. \& C. Baigún. 2002. Performance of a fishway system in a major South American dam on the Paraná river (ArgentinaParaguay). River Research and Applications, 18: 171-183.

Pelicice, F. M. \& A. A. Agostinho. 2008. Fish passage facilities as ecological traps in large Neotropical Rivers. Conservation Biology, 22: 180-188.

Pinto, M. D. C., J. R. B, Melo, I. S. Freitas \& E. E. Marques. 2009. Distribuição longitudinal da abundância de ovos e larvas de peixes no reservatório da UHE Peixe Angical. Pp. 113-119. In: Agostinho, C. S., F. M. Pelicice \& E. E. Marques (Eds.). Reservatório de Peixe Angical: bases ecológicas para o manejo da ictiofauna. São Carlos, RiMa Editora.

Pompeu, P. S., A. A. Agostinho \& F. M. Pelicice. 2012. Existing and future challenges: the concept of successful fish passage in South America. River Research and Applications.

Roscoe, D. W. \& S. G. Hinch. 2010. Effectiveness monitoring of fish passage facilities: historical trends, geographic patterns and future directions. Fish and Fisheries, 11: 12-33.

Suzuki, F. M., L. V. Pires \& P. S. Pompeu. 2011. Passage of fish larvae and eggs through the Funil, Itutinga and Camargos Reservoirs on the upper Rio Grande (Minas Gerais, Brazil). Neotropical Ichthyology, 9: 617-622.

Volpato, G. L., R. E. Barreto, A. L. Marcondes, P. S. A. Moreira \& M. F. B. Ferreira. 2009. Fish ladders select fish traits on migration still a growing problem for natural fish populations. Marine and Freshwater Behaviour and Physiology, 42: 307-313.

Submitted March 15, 2012 Accepted July 9, 2012 